\title{
THE GEOGRAPHICAL DISTRIBUTION OF THE BLACK LOCUST (ROBINIA PSEUDOACACIA L.) IN POLAND AND ITS ROLE ON NON-FOREST LAND
}

\author{
TOMASZ WOJDA ${ }^{1}$, MARCIN KLISZ1 ${ }^{1}$, SZYMON JASTRZĘBOWSKI ${ }^{1}$, \\ MARCIN MIONSKOWSKI ${ }^{2}$, IWONA SZYP-BOROWSKA ${ }^{1}$, \\ KRYSTYNA SZCZYGIEŁ ${ }^{1}$ \\ ${ }^{1}$ Department of Silviculture and Genetics of Forest Trees \\ ${ }^{2}$ Department of Forest Resources Management \\ Forest Research Institute \\ 05-090 Raszyn, Sękocin Stary, 3 Braci Leśnej Street, Poland \\ t.wojda@ibles.waw.pl
}

\begin{abstract}
The black locust (Robinia pseudoacacia L.) has been present in Poland for more than 200 years now, its range coming to encompass the entire country, albeit with a particular concentration of occurrence in the west. Overall, it is present in $3.4 \%$ of the stands making up Poland's "State Forests National Forest Holding" (Państwowe Gospodarstwo Leśne Lasy Państwowe), and is the dominant species in $0.1 \%$ of stands. Thanks to its producing durable wood of favourable energetic properties, this species is used in medium-rotation ( $\leq 40$-year) plantations as well as in biomass energy plantations (where there is a 5-7-year rotation). In terms of its nectar production, the black locust is second only to lime as the Polish tree best serving the production of honey. While the species shows marked expansiveness in Poland, it has not thus far been placed on the list of aliens capable of threatening native species or natural habitats. Breeding of the species has been engaged in - if to only a limited extent - in Poland for some 20 years now, and 2 selected seed stands have been registered, as well as 34 plus trees and 2 seed orchards.
\end{abstract}

KEY WORDS: black locust, distribution, plantation, short rotation, breeding, wood, bee forage, invasive. 


\section{INTRODUCTION}

The genus Robinia comprises 19 botanical taxa, of which 8 are at species level, while the remainder are natural hybrids or varieties (Rédei 2013, Zajączkowski 2013a). The black locust or "robinia" (sometimes also "false acacia") (Robinia pseudoacacia L.) is the only species to produce white flowers (Vinogradova et al. 2013). Its natural range of occurrence is North America, with the Appalachians in the east and the Ozarks and Oachita Hills in the centre. The overall native range of distribution thus extends between $32^{\circ}$ and $43^{\circ} \mathrm{N}$ (Rédei 2013).

The black locust belongs to Fabaceae, within the sub-family Papilionoideae. Like all species thereof, it takes advantage of Rhizobium bacteria present in root nodules in the circumstances of a mutualistic relationship (Danso et al. 1995). This allows the species to fix free nitrogen gas from the air at rates of up to $274 \mathrm{~kg} \mathrm{ha}^{-1}$ year-1 (DeGomez, Wagner 2001). Robinia also enters into symbiotic relationships with mycorrhizal fungi, this inter alia assuring it appropriate amounts of the phosphorus it needs for growth. Across its natural range, typical conditions will allow the tree to reach some $20 \mathrm{~m}$ in height (Cierjacks et al. 2013). However, this is not a more important species from the economic point of view in its native range, on account of the presence of pests that reduce the quality of the wood markedly (Huntley 1990).

Though introduced to Europe at a known moment in history, the black locust does now form recognisable plant associations here, including Chelidonio-Robinietum, Poo nemoralis-Robinietum, Arrhenathero elatioris-Robinietum and Melico transsilvanicaeRobinietum (Vitkova, Kolbek 2010). It is a pioneer species well able to colonise poor and degraded habitats, even where the soil cover has been distorted and degraded. It readily forms larger contiguous patches of a monospecific nature, exerting a negative allelopathic influence on plants of the understorey and ground cover. Despite this, stances as regards its influence on biodiversity are not entirely negative (Benesperi et al. 2012). Indeed, work by Sitzia et al. (2012) and Deneau (2013) was unable to offer definitive evidence or any limiting of biodiversity by the species. Furthermore, there are reports that even suggest a favourable influence of the black locust on the forest environment. For example, robinia woods in areas very much altered by human activity can serve as a refuge for rare saprophytes (e.g. of the genus Lepiota), which are otherwise associated with fertile broadleaved forests. Mycological observations of stands of black locust trees likewise point to the presence of many rare and endangered species, which account for up to $27 \%$ of the entire documented mycobiota (Ślusarczyk 2012). The deep splits regularly present in the bark of older specimens serve as places in which bats seek concealment and shelter during the day. For example, in the Mieszkowice Forest District of western Poland it is common for stands of black locust to support Nathusius's pipistrelle bats (Pipistrellus nathusii Keyserling \& Blasius), while deeper holes are regularly nested in by hoopoes (Upupa epops) - a species apparently in decline in Europe. 
A 1601 introduction date makes the black locust the first tree to be brought to Europe from America (Tokarska-Guzik 2005). Seed pods were in fact transported from Canada by Jean Robin (1550-1629), hence the name. Robin was a botanist, and a gardener to Kings of France Henry IV and Louis XIII (Zajączkowski 2013b).

At the outset, the species was deployed as a decorative park tree. However, by the second half of the $18^{\text {th }}$ century it had started to be cultivated for its wood in France, Germany and Hungary (Banach et al. 2013). Today it occurs around the world, though most abundantly in Europe (if largely) absent from Lithuania, Latvia, Estonia, Denmark, Norway, Finland and the Balkans (Cierjacks et al. 2013, DAISIE 2006). Naturally it is widely present in the USA and Canada, but also in Mexico, Chile, Bolivia and Argentina, and then in Africa (notably South Africa and Nigeria), as well as Australia, Indonesia, and Asian countries including China, Japan, Korea, Afghanistan and Pakistan. Overall it is present in at least 35 countries (Guoqing et al. 2014), and - after eucalyptus species and poplar hybrids - is the most commonly cultivated tree in the world (DeGomez and Wagner 2001).

The wood of the black locust has exceptional properties that have ensured a wide variety of applications for the species. In a tree aged 46 years, the heartwood will typically account for as much as $99.6 \%$ of the cross-sectional area (Klisz et al. 2015). Being both exceptionally durable - with heartwood lasting 1500 years where dry, 500 years in water and 80 years if exposed to the elements outdoors (Pacyniak 1981) and characterised by considerable decorative value (resembling teak), the wood of the black locust has been found uses in the manufacture of both garden furniture and parquet flooring (the latter often in pleasing combination with the wood of species such as wild cherry). A traditional use is as supports for vines or else as fence posts in forestry. In this case it is usual for repeat use to be an option, the simple expedient being to turn the poles over and bury the hitherto-exposed ends in the soil.

The wood of the black locust also has very favourable energetic properties. The specific calorific value is in this case of some $11.8 \mathrm{GJ} \mathrm{m}^{-3}$ (cf. hornbeam or beech with a value of 10.8). This leaves the wood comparable as a fuel with anthracite (the type of coal of greatest carbon content). The energy obtainable from $2.5 \mathrm{t}$ (i.e. c. $3.3 \mathrm{~m}^{3}$ ) of wood of this species of $12 \%$ moisture content is the same as that yielded by 1 tonne of fuel oil (Molnár and Németh 1983). Furthermore, the very low (30\%) moisture content in fresh wood ensures that burning is possible without prior drying, while the white ash generated by combustion does not tend to block chimneys. The yellow colour has ensured the nickname "golden wood" for the product from this species.

The widespread occurrence of the black locust in Europe is founded upon more than the properties of its wood. Intensive growth at a young age, a well-developed root system penetrating the surface layer of the soil very effectively, a marked capacity for vegetative propagation (by root cuttings and coppicing) and seeds that remain viable for long periods are all features that have assured spontaneous expansion of the species. However, in line with its high level of utility, it may - if grown on non- 
forest land (plantations, former farmland, degraded areas, other areas of tree-planting) - represent an additional source of valuable timber, as well as a bee-forage. Overall, the biological properties are such as to ensure that good use can be made of the black locust in wood production in the context of the plantation growing of fast-growing species.

\section{OCCURRENCE IN POLISH FORESTS}

At present, the black locust occurs most frequently in the forest growing on Poland's fresh mixed broadleaved and fresh mixed coniferous forests sites (43 and $32 \%$ respectively). On the land under State Forestry management it is present in 88 500 forest sub-compartments covering a total of 273000 ha. The range extends across almost the entire country, though with the greatest preponderance in the west. In central Poland, a key area of occurrence is the industrialised Bełchatów Forest District, where the species has been used successfully for 30 years now in the reclamation of areas around coal mines and power plants. The Forest Districts in which the black locust is most abundant have stands in which it is present (in the lower layer) across areas of up to 5700 ha (as in Cybinka FD), or with a total growing stock (in the form of trees or elements of the understorey) exceeding $100000 \mathrm{~m}^{3}$ (as in Sulechów FD). Overall, among the 430 Forest Districts across Poland, only 11 are distinguished by a complete absence of the species (Fig. 1).

The species is present (in all layers and at whatever level of abundance) in stands whose overall area equals 3.4\% of the National Forest Holding of Poland's State Forests (Państwowe Gospodarstwo Leśne Lasy Panstwowe - PGL LP). Within this category of stand, $3.0 \%$ by area or $6.2 \%$ by numbers of trees can be regarded as dominated by black locust. The greatest numbers of such stands are in the forests of the Zielona Góra Regional Directorate of the State Forests (reaching $11.1 \%$ of the total there). This is followed by the RDSFs of Poznan (8.6\%); Łódź (7.4\%) and Szczecin $(5.7 \%)$. At the bottom of the ranking there are the Regional Directorates of Szczecinek $(0.3 \%)$; Białystok (0.4\%); Olsztyn (0.4\%) and Krosno $(0.8 \%)$. The stands in which the main layer is at least $30 \%$ robinia account for $0.15 \%$ of the total for the PGL LP as a whole (though with as much as $0.8 \%$ in the case of the Zielona Góra RDSF; and $0.4 \%$ where those of Szczecin and Poznan are concerned). The greatest stand areas in which black locust is the dominant species are in the Zielona Gora RDSF (in excess of 2200 ha), in Szczecin (1 700 ha), Poznań (900 ha) and Wrocław (800 ha). At the other end of the scale are the RDSFs of Białystok and Szczecinek, which each support contiguous stands with a preponderance of black locust trees covering less than 10 ha. In Poland as a whole, this is the dominant species over $0.1 \%$ of the State Forests stands. In the case of stands in which more than half of all trees are black locust, the greatest areas are to be found in the Forest Districts of Pieńsk (22.3 ha area), Konin (19.5 ha) and Miechów (17.1 ha). In turn, in the case of the 10 largest sub-compartments 


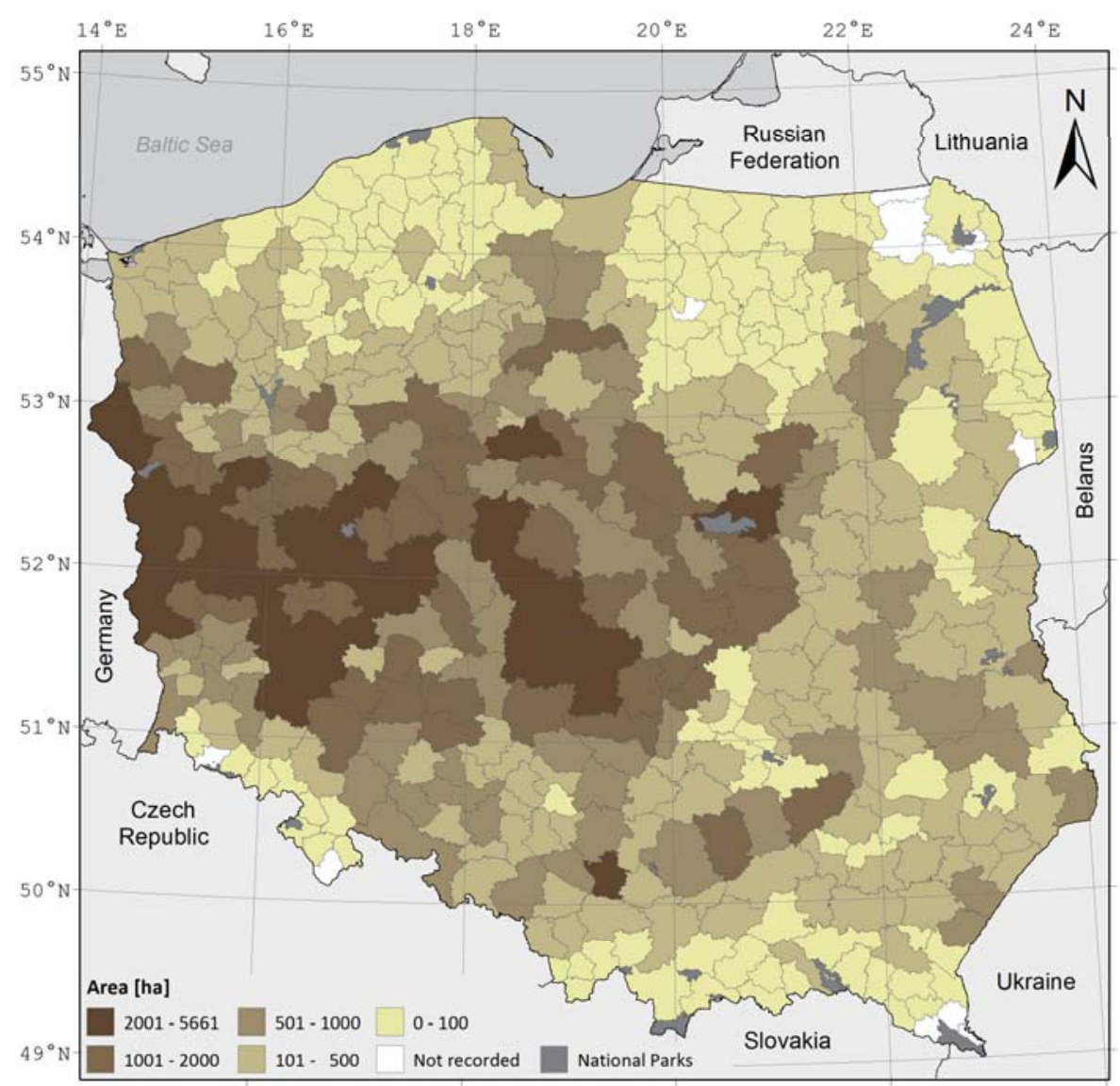

Figure 1. Area of occurrence of the black locust in Poland (in all layers and with whatever share of the forests on State Forest's land)

in which more than $80 \%$ of stand trees are of the species in question, no fewer than 5 are present in the Sulechów FD (Zielona Góra RDSF), the largest in terms of area being of $12.8 \mathrm{ha}$. In turn, stands in which the main layer has at least $10 \%$ of trees of this species cover a total of 39300 ha, the average size of the stands in this category being 2.09 ha.

In 2012, the overall State Forests' harvest of black locust trees was of $83600 \mathrm{~m}^{3}$. More than $25000 \mathrm{~m}^{3}$ of this total was accounted for by the Zielona Góra RDSF, as followed by Szczecin (over 20 000) and Poznań (13 $\left.000 \mathrm{~m}^{3}\right)$. Fuel wood (S4) accounted for $57.6 \%$ of the total, with category S2 accounting for a further $26.3 \%$ of the harvest. Demand for the wood of the species varies markedly from region to region. Paradoxically, in places where it occurs in abundance demand may outstrip supply (since the wood is often exported, above all to The Netherlands). Elsewhere in the country it may be hard to find a market. 


\section{BREEDING IN POLAND}

The black locust was brought to Poland in 1806 (Tokarska-Guzik 2005). General Dezydery Chłapowski opted to use it in the planting of windbreaks at Turew near Kościan (Zajączkowski 2013a). The species began to be planted out in forests in the Wielkopolska region around 1860 (Pacyniak 1981). Pacyniak (1992) notes that Poland's oldest-known black locust tree was (in that year) a 207-year-old specimen by a building of the Jagiellonian University in Kopernika Street, Kraków. Happily, the tree lives on, though it is now 230 years old. The stoutest specimen in Poland (with a girth of 507 $\mathrm{cm}$ ) is a single-trunk specimen branching some $4 \mathrm{~m}$ above the ground that grows within Sulechów FD, in compartment 74 as of the Klemsko sub-district (Banach et al. 2013).

It is nevertheless quite typical for the black locust to be regarded as an undesirable alien in Poland. In the view of the Invasive Species Specialist Group (ISSG) operating under the aegis of the World Conservation Union (IUCN), the black locust exerts a negative impact on forest ecosystems (Woziwoda 2012, Moore 2005). However, in Poland it has not been listed as an alien species capable of threatening native species or habitats see the Official Journal of Laws of 2011, no. 210, item 1260 (Dziennik Ustaw... 2011). Likewise, the "Program of conserving forest genetic resources and breeding of trees in Poland for the years 2011-2035" (Program zachowania leśnych zasobów genowych $i$ hodowli selekcyjnej drzew w Polsce na lata 2011-2035) does not include the robinia on its list of invasive species, while noting that this is among the species alien to Poland that is of certain economic significance to the State Forests, which does therefore engage in limited silvicultural and selective activity in regard to it (Program... 2011).

It is possible to distinguish (at least) the two basic forms of the tree known as "typical" or "straight-trunked" (shipmast stem form). By far the most commonly-metwith and prevalent form is the "typical" one, which is taken to denote a short tree (of $5 \mathrm{~m}$ or less in height), which is often twisted, often growing at a sloping angle and with the crown set rather close to the ground. Trees growing in contiguous stands may also be twisted in various directions (Zajączkowski 2013b). Stands of the latter kind are typical for poor habitats, while similar trees can be encountered in wayside belts of tree-planting, and in circumstances of $a d$ hoc origin with no silvicultural care extended. It is typical for such trees to be seen in an unreservedly negative light (Danielewicz 2013). In turn, the straight-trunked trees have a genetically-fixed capacity to produce straight trunks that are clean to a far greater height above the ground, even where they grow singly. The crowns in these circumstances are more regular, while the limbs are less stout, and the branches thinner and less thorny (Zajączkowski 2013b). The straight-trunked form was one described as a separate variety, i.e. $R$. pseudoacacia L. var. rectissima Raber, though now it is seen as nothing more than an ecotype. Besides its visible anatomical feature, this ecotype is more resistant to damage caused by the locust borer Megacyllene robiniae Forst., as well as to the trunk rot induced by Fomes rimosus (Berk.). On the other hand, it produces few seeds and is usually therefore propagated by vegetative means. 
In Poland, more than 20 years of selective cultivation of the black locust by the State Forests has resulted in the selection of 5 seed stands of total area 10.25 ha; 2 selected seed stands covering 5.29 ha in total and 34 plus trees. Two seed orchards covering a total of 6.74 ha have also been established, one of these being of Hungarian origin. The "Programme" (Program... 2011) currently in place to deal with the period to the end of 2035 anticipates further increases of the seed base for the species by some 20 plus trees, as well as an increase in the area of progeny plantations in 50 ha blocks. It is at the same time stressed that the enhanced seed base is to supply material for the establishment of fast-growing plantations on former farmland, rather than to increase the range of the species or the role it plays in forests (Kowalewski 2013).

Data from Poland's central stand assessment database (the so-called Centralny Opis Taksacyjny) has allowed for a review of the stands across the country in which black locust play a more significant role, and then for the identification of several in which the trees present have particularly straight trunks (Tab. 1). Straight-trunked specimens were then used as a source of root cuttings, with saplings being grown from these, and a clone archive established in 2014, to serve as a base for the most valuable stands including the species. The archive is located in Torzym Forest District in western Poland, and

Table 1. Straight-trunked black locust stands in Poland, as of 2012

\begin{tabular}{|c|c|c|c|c|c|c|c|c|}
\hline 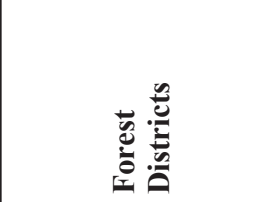 & 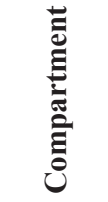 & 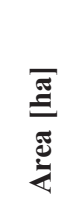 & 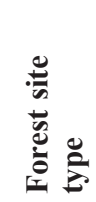 & $\underset{0}{20}$ & 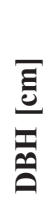 & 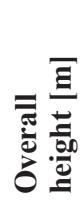 & 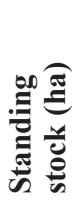 & 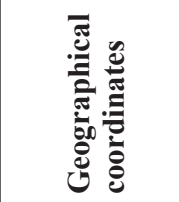 \\
\hline Krosno & $90 \mathrm{~b}$ & 1.14 & LMśw & 30 & & & 149 & $\begin{array}{llll}\text { N } & 52 & 5 & 40.2 \\
\text { E } & 14 & 58 & 13.7\end{array}$ \\
\hline Krosno & $232 \mathrm{i}$ & 3.18 & LMśw & 83 & & & 389 & $\begin{array}{llll}\text { N } & 52 & 8 & 24.1 \\
\text { E } & 14 & 55 & 14.3\end{array}$ \\
\hline Cybinka & $98 y$ & 1.05 & LMśw & 64 & 27 & 27 & 276 & 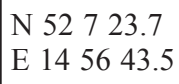 \\
\hline Wołów & $194 f$ & 2.86 & BMśw & 43 & 17 & 19 & 137 & $\begin{array}{llll}\text { N } & 51 & 25 & 12.5 \\
\text { E } & 16 & 34 & 41.8\end{array}$ \\
\hline Pińczów & $426 f$ & 3.29 & LMśw & 30 & & & 182 & 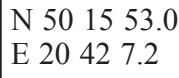 \\
\hline Strzelce & $150 \mathrm{Am}$ & 1.36 & LMśw & 40 & 19 & 16 & 111 & $\begin{array}{llll}\text { N } & 50 & 29 & 37.7 \\
\text { E } & 18 & 2 & 54.2\end{array}$ \\
\hline Mieszkowice & $210 \mathrm{j}$ & 1.31 & LMśw & 42 & 22 & 21 & 196 & $\begin{array}{llll}\text { N } & 52 & 51 & 31.5 \\
\text { E } & 14 & 11 & 40.7\end{array}$ \\
\hline $\begin{array}{l}\text { Wyszanów (private } \\
\text { stand) }\end{array}$ & - & 0.70 & - & 50 & & & - & $\begin{array}{l}\text { N } 5112139.9 \\
\text { E18 }\end{array}$ \\
\hline
\end{tabular}

Explanations: LMśw - fresh mixed broadleaved forest, BMśw - fresh mixed coniferous forest, DBH - Diameter at Breast Height. 
it currently includes saplings representing 28 clones from 6 straight-trunked stands of the species. The archive has a $5 \times 5 \mathrm{~m}$ spacing, and will serve as a source for the collection of root material for cuttings, allowing for the further vegetative propagation of material usable in the establishment of new plantations.

\section{LONG-ROTATION PLANTATIONS}

While the black locust is a highly expansive species, its use as a fast-growing plantation tree must nevertheless denote the choice of a proper location from the point of view of both site and humidity conditions. Under the natural conditions pertaining in Poland, the plantations will first and foremost be established in the west and south-west of the country, and at altitudes of $300 \mathrm{~m}$ a.s.1. or less (Zajączkowski 2013a). Only the best soils will suffice, of quality classes III-IV, humus-rich and well-aerated. Agriculturetype preparation of the soil for planting is required, with deep ploughing, followed by a winter period in which the soil is left exposed in sharp furrows. There should then be careful levelling of the surface in spring. Permanent fencing is indicated, to protect the trees from browsing. Plantation trees should derive solely from selected clones with genetically fixed growth attributes. Seedlings of this kind are most often obtained through vegetative propagation, via root cuttings. However, the cost of a seedlings produced in this way is more than 10 times as great as where generative propagation (growth from seed) is applied. Nevertheless, in 2013, the Forest Research Institute at Sękocin Stary succeeded in developing a method of in vitro vegetative reproduction (micropropagation) involving organogenesis.

The plantation spacing should be of 1.6-2.0 $\times 2.5 \mathrm{~m}$. The first cleaning takes place when stand closure is achieved, i.e. after $4-5$ years. This measure should see the number of specimens reduced to about 2500 per ha. Late cleaning would then take place two years later, with a resultant density reduction to around 1700 trees per ha. During the first 3-4 years efforts are made to train the guiding shoots, with the first pruning of trunks carried out after the early cleaning. This measure needs to be repeated every 2-3 years in such a way that the trunk free of branches achieves a target height of 4-6 m. When trees are 12-16 years late selective thinning is carried out to create good conditions for selected future trees (some 400-700 of these per ha). At the ages of 22-25 years, further thinning to allow more light into the stand should be carried out, with the result that some 500-600 trees per ha remain for the harvest cut (Zajączkowski 2013a).

Black locust of yield class I will have reached $27 \mathrm{~m}$ in height at the age of 40 years, and have a breast-height diameter of $32 \mathrm{~cm}$, a growing stock of $425 \mathrm{~m}^{3} \mathrm{ha}^{-1}$ and growth increments equal to $14 \mathrm{~m}^{3} \mathrm{ha}^{-1}$ year-1 $^{-1}$ (Rédei 2013). In Germany (specifically Brandenburg), 50-year-old trees of yield class I have a growing stock of $400 \mathrm{~m}^{3} \mathrm{ha}^{-1}$, this reaching $550 \mathrm{~m}^{3} \mathrm{ha}^{-1}$ at age 100 (Panka 2013). In turn, where yield class IV specimens are concerned, an age of 30 is associated with a growing stock of $235 \mathrm{~m}^{3} \mathrm{ha}^{-1}$ and an average volume increment of $8 \mathrm{~m}^{3} \mathrm{ha}^{-1}$ year-1 (Rédei 2013). However, long-rotation 
plantations of this species are not being established in Poland at present, as the lengths of the periods involved to obtain large timber (30-40 years) is regarded by farmers as unacceptably long (Zajączkowski 2013b).

\section{SHORT-ROTATION PLANTATION}

A greater demand for wood for energetic purposes has necessitated an ongoing search for new sources of raw material. Selection among black locust for better production of fuelwood has been practised in Hungary for a long time now, with the result that there are several vegetatively propagated cultivars there - including Jaszkiseri, Üllöi, Nyirsegi and Rozsaszin AC - which are usable in fuelwood plantations. In optimal rotation cycle, 5 years on from the time of planting (in a $1.5 \times 1 \mathrm{~m}$ spacing), these varieties can be producing 7.3-8.0 $\mathrm{t} \mathrm{ha}^{-1}$ year-1 of dry mass. Non-selected black locust of the "ordinary" kinds would at that point be producing $6.7 \mathrm{t} \mathrm{ha}^{-1}$ year-1 (Rédei et al. 2013). However, German experience points to much higher potential productivity. There, cultivated (but not specially-selected) black locust planted with an irregular spacing can yield $4.7 \mathrm{t} \mathrm{ha}^{-1}$ year-1 of dry mass on a one-year rotation, while a 4-year cycle offers $8.2 \mathrm{t} \mathrm{ha}^{-1}$ year-1 $^{-1}$. The authors involved in the work in question (Engel et al. 2013) note that, with fully suitable soil quality and planting density, a dry-mass output of even $9.98 \mathrm{t} \mathrm{ha}^{-1}$ year-1 $^{-1}$ is achievable.

Hitherto, Poland had lacked studies on the short-rotation production of black locust trees for energy purposed. The first experiments with the short-rotation cultivation of the species were started in Torzym FD (western Poland) in 2013. Applying 2.5 x $1 \mathrm{~m}$ spacing, tests are being carried out on four Hungarian clones known as A32, A49, A69 and A88, by way of vegetatively propagated seedlings from a seed orchard in Oborniki Śląskie FD, as well as "Turbo" seedlings produced commercially by the Hungarian firm Silvanus using generative propagation. Beyond that, there is a separate experiment - also established in 2013 - in Torzym FD, in which comparisons are being made between the productivity of black locust trees grown in spacing of $1.5 \mathrm{x} 1 \mathrm{~m}$; $2.5 \times 1 \mathrm{~m}$ or $2 \times 2 \mathrm{~m}$.

\section{BLACK LOCUST AS BEE FORAGE}

Beekeepers are very interested in the black locust remaining in the Polish landscape at least the level achieved hitherto. In terms of the nectar content in its flowers, the species is second only to lime in terms of its capacity to generate honey in Polish hives. In countries with a slightly warmer climate (Romania, Hungary or Bulgaria), as much as $50 \%$ of the honey sold commercially derives from black locust flowers. Indeed, this is a key forest tree species in Hungary, with stands of this kind accounting for $23 \%$ of the country's forest cover. In turn, $25 \%$ of the forests in Hungary are put to use by 
beekeepers, with more than $90 \%$ of the area involved being dominated by robinia. Varieties of the tree apparently favouring greater production of honey have even been selected in Hungary, whose mean annual output of the product is around 25000 tonnes per year (earning some $€ 15 \mathrm{M}$ in income - Csiha 2013). At the time of most abundant flowering of black locust, hives may even show average weight increases of $10 \mathrm{~kg}$. A tree a little over ten years old may support some 25-100 000 flowers, this implying 15-40 million flowers per hectare. In Hungarian conditions, 30 years of production of "acacia honey" is of itself enough to offset the costs of establishing a plantation of black locust trees over 1 ha of land. Of course, a tree's output in terms of nectar and subsequently honey changes with age, peaking at the age of 15-16 years with 835 and $418 \mathrm{~kg} \mathrm{ha}^{-1}$ respectively (Csiha 2013). The capacity to generate honey is lower in Polish conditions, amounting to some $100 \mathrm{~kg}$ per ha, or enough to support just 5-6 strong families of honeybees per ha. In comparison, rape, whose capacity is believed to be similar, is recommended for just 1-2 bee families per ha (Kołtowski 2013). Thanks to its higher content of fructose, as opposed to glucose, "acacia honey" remains uncrystallised for longer and boasts a saccharose content that (at 11\%) is higher than in any other kind of honey.

\section{OTHER USES OF THE BLACK LOCUST}

There is no doubt that this species present across almost the whole of Poland has an unfavourable overall influence on biological diversity and the functioning of natural ecosystems, and should not therefore be used in the founding of plantations on forest land. At the same time, it needs to be accepted that the complete removal of the black locust from forests at this stage would represent a near-impossible task (Bellon 2006). Furthermore, on account of its utility value, its suitability for planting on non-forest land (in plantations, on former farmland, in degraded areas, on small plots needing rapid tree cover), the species may represent a further valuable source of wood, as well as being extremely helpful to beekeepers. As early as in the 1980s, Bellon et al. (1977) recognised that the black locust was more suitably used in the reclamation of degraded areas or in plantation work, than in managed forests.

Indeed, there would seem to be no more suitable tree than the black locust when it comes to tree-planting on degraded land and in those areas where nitrogen is a nutrient either of limiting status or accumulating at an uneven rate (Rahmonov 2009). In such circumstances, it surpasses other tree species in terms of survival, increase in biomass and favourable influence on the properties of reclaimed land. Thanks to its attributes, the black locust is also used in the biological reclamation of landfill sites and spoil heaps (Gruenewald et al. 2007). Zajączkowski (2013b) even postulates conferment of the status of accepted forest tree species on the black locust, in the areas where larger contiguous stands with a major share taken by the species are present. This would particularly be the case for western Poland (and above all its Ziemia Lubuska region), 
with which the black locust now has a long association. As in Hungary, it should also be permissible for stands of straight-trunked robinia to be planted out using material from cuttings (Zajączkowski 2013b).

\section{ACKNOWLEDGMENTS}

This work was supported by the State Forests National Forest Holding.

\section{REFERENCES}

Banach L., Wiler M., Maciantowicz M., 2013, Występowanie robinii akacjowej na obszarze RDLP w Zielonej Górze,(Distribution of black locust in the area of Regional Directorate of the State Forest in Zielona Góra), [in:] Robinia akacjowa w krajobrazie Ziemi Lubuskiej, (Black locustin the landscape of Ziemia Lubuska province), Materiały konferencyjne, (Proceedings), Łagów, 5-21.

Bellon S., 2006, Obce gatunki drzew a pótnaturalna hodowla lasu, (Alien species of trees and semi-natural silviculture), [in:] Sabor J. (ed.), Elementy genetyki i hodowli selekcyjnej drzew leśnych, (Elements of genetics and forest tree breeding), CILP, Warszawa, 309-314.

Bellon S., Tumiłowicz J., Król S., 1977, Obce gatunki drzew w gospodarstwie leśnym, (Alien species of trees in forest management), PWRiL, Warszawa, $267 \mathrm{pp}$.

Benesperi R., Giuliani C., Zanetti S., Gennai M., Lippi M.M., Guidi T., Nascimbene J., Foggi B., 2012, Forest plant diversity is threatened by Robinia pseudoacacia (black-locust) invasion, Biodiversity and Conservation, 21, 14, 3555-3568.

Cierjacks A., Kowarik I., Joshi J., Hempel S., Ristow M., Lippe M., Weber E., 2013, Biological Flora of the British Isles: Robinia pseudoacacia, Journal of Ecology, 101, 1623-1640.

Csiha I., 2013, Black locust forest as bee-forage, [in:] Rédei K. (ed.), Black locust (Robinia pseudoacacia L.) growing in Hungary, Sárvár, 72-73.

DAISIE European Invasive Alien Species Gateway, 2006, Robinia pseudoacacia, http://www. europe-aliens.org/speciesFactsheet.do?speciesId=11942 (2012-10-03)

Danielewicz W., 2013, Obce gatunki drzew w leśnictwie - cele, kryteria oceny $i$ wyniki introdukcji, (Alien speciesin forestry - aims, evaluation criteria and results of introduction), Post. Tech. Leś., 121, Hodowla lasu a trwałość i stabilność drzewostanów, (Silviculture and sustainability of forest stands), 36-41.

Danso S.K.A., Zapata F., Awonaike K.O., 1995, Measurement of biological N2 fixation in fieldgrown Robinia pseudoacacia L, Soil Biology and Biochemistry, 27, 415-419.

DeGomez T., Wagner M.R., 2001, Culture and use of black locust, Horttechnology, 11, 279-288.

Deneau K., 2013, The effects of black locust (Robinia pseudoacacia L.) on understory vegetation and soils in a northern hardwood forest, Swedish University of Agricultural Sciences, Master Thesis no. 212, Alnarp.

Dziennik Ustaw (Dz. U.), 2011, nr 210 poz. 1260 - rozporządzenie ministra środowiska z dnia 9 września 2011 r. w sprawie listy roślin i zwierząt gatunków obcych, które w przypadku uwolnienia do środowiska przyrodniczego mogą zagrozić gatunkom rodzimym lub siedliskom 
przyrodniczym, (Official Journal of Laws of 2011, no. 210, item 1260 - Regulation of the Minister of the Environment of September 9 $9^{\text {th }} 2011$ on lists of alien plant and animal species whose release to the natural environment may threaten native species or natural habitats).

Engel J., Knoche D., Lange C., 2013, Opracowanie innowacyjnych metod zagospodarowania drzewostanów robinii akacjowej, (Elaboration of innovative methods of black locust tree stands management), [in:] Robinia akacjowa w krajobrazie Ziemi Lubuskiej, (Black locustin the landscape of Ziemia Lubuska Provence), Materiały konferencyjne, (Proceedings), Łagów, 85-104.

Gruenewald H., Brandt B.K.W., Schneider B.U., Bens O., Kendzia G., Hüttl R.F., 2007, Agroforestry systems for the production of woody biomass for energy transformation purposes, Ecological Engineering, 29, 4, 319-328.

Guoqing L., Guanghua X., Ke G., Sheng D., 2014, Mapping the global potential geographical distribution of Black locust (Robinia Pseudoacacia L.) using herbarium data and a maximum entropy model, Forests, 5, 2773-2792.

Huntley J.C., 1990, Robinia pseudoacacia L. black locust, Silvics of North America, Agriculture Handbook, 654, U.S. Department of Agriculture, Forest Service, Washington, 2, 755-761.

Klisz M., Wojda T., Jastrzębowski S., Ukalska J., 2015, Obwodowa zmienność drewna twardzielowego $w$ drzewostanach robinii akacjowej, (Circumferential variation of heartwood in tree stands of black locust), Drewno (in press).

Kołtowski Z., 2013, Robinia akacjowa jako pożytek pszczeli, (Black locust as bee forage), [in:] Robinia akacjowa w krajobrazie Ziemi Lubuskiej, (Black locust in the landscape of Ziemia Lubuska"Province), Materiały konferencyjne, (Proceedings), Łagów, 105-108.

Kowalewski M., 2013, Wpływ obcych gatunków drzew na ekosystemy leśne, (Impact of alien tree specieson forest ecosystems), Post. Tech. Leś., 121, Hodowla lasu a trwałość i stabilność drzewostanów, (Silviculture and sustainability of forest stands), 30-35.

Molnár S., Németh K., 1983, Investigations into the heat of combustion and heating value of black locust, Faipar, 33, 3, 78-79.

Moore B.A., 2005, Alien invasive species: impact on forest and forestry. A review, Forest Resources Development Service, Working Paper FBS/8E, FAO, Rome.

Pacyniak C., 1981, Robinia akacjowa (Robinia pseudoacacia L.) w warunkach środowiska leśnego w Polsce, (Black locust - Robinia pseudoacacia L. - in conditions of Polish forest environment), Rocz. AR w Poznaniu, Rozpr. Nauk., 111, Poznań, 85 pp.

Pacyniak C., 1992, Najstarsze drzewa w Polsce, przewodnik, (The oldest trees in Poland, guidebook), Wydawnictwo PTTK "Kraj", Warszawa, 204 pp.

Panka S. 2013, Wzrost i rozwój robinii akacjowej na obszarze pótnoco-wschodniej Niziny Niemieckiej na przyktadzie statych powierzchni badawczych, (Growth and development of black locust in the north-east German Lowlands on the example of permanentre search plots), [in:] Robinia akacjowa w krajobrazie Ziemi Lubuskiej, (Black locust in the landscape of Ziemia Lubuska Provence), Materiały konferencyjne, (Proceedings), Łagów, 30-44.

Program zachowania leśnych zasobów genowych i hodowli selekcyjnej drzew w Polsce na lata 2011-2035, 2011, (Program of conserving forest genetic resources and breeding of trees in Poland for the years 2011-2035), CILP, Warszawa.

Rahmonov O., 2009, The chemical composition of plant litter of black locust (Robinia pseudoacacia L.) and its ecological role in sandy ecosystems, Acta Ecologia Sinica, 29, 237-243. 
Rédei K., 2013, Black locust (Robinia pseudoacacia L.) growing in Hungary, ERTI, Sárvar, $76 \mathrm{pp}$.

Rédei K., Borovics A., Keserü Z., 2013, Breeding and improvement of black locust, [in:] Rédei K. (ed.), Black locust (Robinia pseudoacacia L.) growing in Hungary, Sárvár, 15-19.

Sitzia T., Campagnaro T., Dainese M., Cierjacks A., 2012, Plant species diversity in alien black locust stands: A paired comparison with native stands across a north-Mediterranean range expansion, Forest Ecology and Management, 285, 85-91.

Ślusarczyk T., 2012, Lasy robiniowe ostoja rzadkich i zagrożonych grzybów wielkoowocnikowych, (Robinia forests as a refuge for rare and threatened macrofungi), Przegląd Przyrodniczy, 23, 2, 11-41.

Tokarska-Guzik B., 2005, The establishment and spread of alien plant species (kenophytes) in the flora of Poland, Wydawnictwo Uniwersytetu Śląskiego, Katowice, 192 pp.

Vinogradova Y., Tkacheva E., Brinzda J., Mayorov S., Ostrowsky R., 2013, On flowering patterns of alien species: 2. Robinia pseudoacacia, Russian Journal of Biological Invasions, 4, 2, 74-86.

Vítková M., Kolbek J., 2010, Vegetation classification and synecology of Bohemian Robinia pseudacacia stands in a Central European context, Phytocoenologia, 40, 2/3, 205-241.

Woziwoda B., 2012, Inwazje drzew introdukowanych $w$ celach komercyjnych jako problem globalny, (Invasions of tree species introduced in commercial purposes as a global problem), Studia i Materiały CEPL w Rogowie, R. 14, Zeszyt 33, 4, 113-120.

Zajączkowski K., 2013a, Hodowla lasu. Plantacje drzew szybko rosnacych, (Silviculture. Plantations of fast-growing trees), PWRiL, Warszawa, $168 \mathrm{pp}$.

Zajączkowski K., 2013b, Robinia akacjowa - wartościowy gatunek. Plantacyjna uprawa robinii (Black locust - valuable species. Plantation of black locust), [in:] Robinia akacjowa w krajobrazie Ziemi Lubuskiej, (Black locustin the landscape of Ziemia Lubuska Province), Materiały konferencyjne, (Proceedings), Łagów, 73-84. 